\title{
Use of Rio Grande Plain Brush Types by White-tailed Deer
}

\section{CRAIG A. McMAHAN AND JACK M. INGLIS}

Highlight: The relative use of 11 major brush types and a rootplowed area by white-tailed deer was studied on the San Pedro Ranch in Dimmit County, Texas. The mesquite drainage, hackberry drainage, and guajillo scrub types were preferred by deer in fall, winter, and spring. In summer, the mesquite drainage was preferred and all other types were used about equally. The granjeno drainage, rootplowed, and mesquite savannah types were used least. The preferred brush types occurred on sandy loam soils. The composition, density (within a range of tolerance), structure, and phenology of brush were not important factors influencing selection of types by deer. The quality of typical brushlands as deer habitat appeared to be largely a function of range site. Range sites capable of high gross production of herbaceous plants deserve consideration for their value to deer in brush clearing schemes. Some brush should be left intact as screening cover on such sites to insure continuing deer populations on ranches practicing brush control in the Rio Grande Plain.

During the last 30 years large scale brush clearing to improve rangeland for cattle has occurred over the Rio Grande Plain of Texas-a region known for its trophy-sized whitetailed deer (Odocoileus virginianus). Increase in brush and cacti has reduced range carrying capacity for cattle in South Texas and has led to clearing operations. Brush is little browsed by cattle, but some brush is an essential attribute of most deer habitats. Brush clearing continues; but wildlife conservationists, aware of the need for range management plans that consider wildlife, still cannot explain exactly which of the plant communities in the brush formation provide good habitat for white-tailed deer, nor the reasons for the hypothesized selection of the communities.

Historically, the Rio Grande Plain was an open grassland interspersed with low, stunted brush on the gravelly hills, in erosional breaks, and along some drainages (Johnston, 1963;

Authors are research assistant and associate professor, Department of Wildlife and Fisheries Sciences, Texas A\&M University, College Station. At present the senior author is wildlife planner, Texas Parks and Wildlife Department, John H. Reagan State Office Building, Austin, Texas.

The project was cooperative between the Texas Parks and Wildlife Department (P.R. Project W-84-R) and the Texas Agricult ural Experiment Station (Project S-1203). This is contribution number TA-10779 of the Texas Agr. Exp. Sta.

Manuscript received October 10, 1973.
Inglis, 1964). Now, however, the designation thorn shrub (Muller, 1947) probably best describes the physiognomy of the region.

Davis and Spicer (1965) surveyed the extent of brush control, and Inglis (1964) reviewed the history of the vegetation in the Rio Grande Plain. Davis and Winkler (1968) reported the effects of rootplowing on some populations of deer and the food habits of decr in cleared and uncleared habitat.

Objectives of the study were to evaluate the relative use of major brush types by white-tailed deer in the Rio Grande Plain, to determine the influence of plant abundance and phenology in the selection of brush types, and to investigate the influencc of ecological factors in deer selection of site. The project aimed at providing ranchers with alternatives to complete clearing of brushlands used by wildlife.

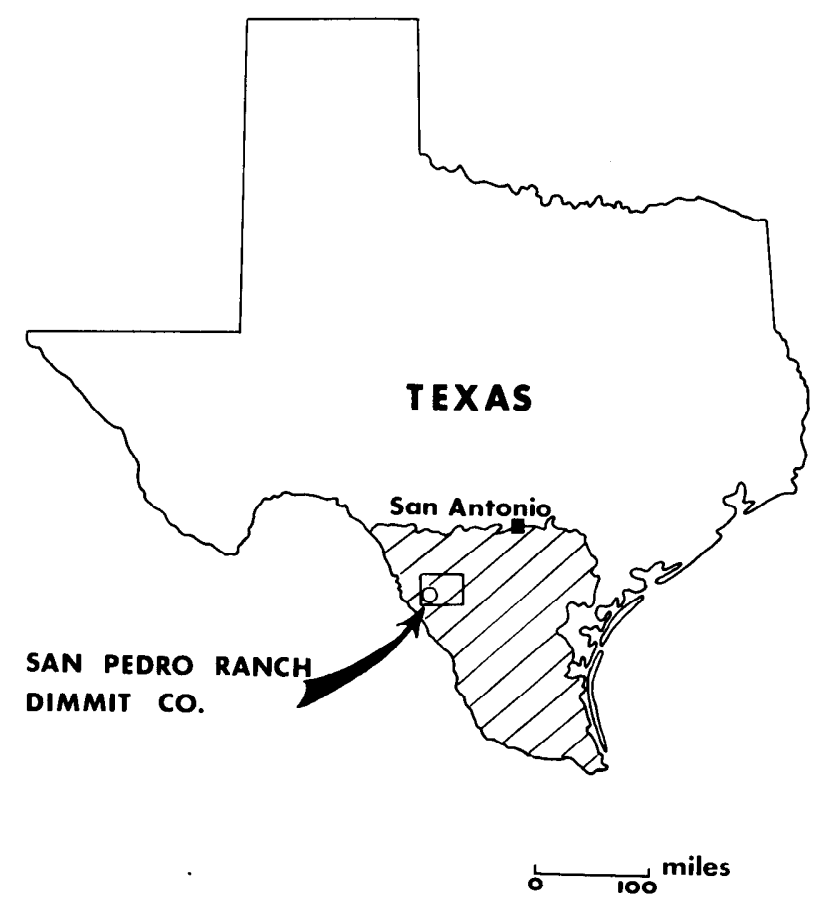

Fig. 1. The Rio Grande Plain, hatched, and location of study area. 
Table 1. Characteristics of examples of brush types sampled for deer pellet-groups.

\begin{tabular}{|c|c|c|c|c|c|c|}
\hline Name & $\begin{array}{l}\text { Average brush } \\
\text { thickness }^{1}\end{array}$ & $\begin{array}{c}\text { Average brush } \\
\text { height }^{2}\end{array}$ & Soil mapping unit & Range site & $\begin{array}{c}\text { Acres in } \\
\text { units sampled }\end{array}$ & $\begin{array}{l}\text { No. } 0.01- \\
\text { acre plots }\end{array}$ \\
\hline Mesquite drainage & Thick & High & Miguel fine sandy loam & Tight sandy loam & 40 & $29 *$ \\
\hline Guajillo scrub & Moderate & Low & Dilley fine sandy loam & Shallow sandy loam & 120 & 30 \\
\hline Hackberry drainage & Thick & High & Miguel fine sandy loam & Tight sandy loam & 27 & 7 \\
\hline Mesquite woodland & Moderate & High & Randado fine sandy loam & Shallow sandy loam & 198 & 50 \\
\hline Mixed scrub & Moderate & Low & Zapata gravelly loam & Shallow ridge & 92 & 23 \\
\hline Colubrina scrub & Thin & High & Duval loamy fine sand & Loamy sand & 64 & 16 \\
\hline Blackbrush scrub & Moderate & Low & Zapata gravelly loam & Shallow ridge & 186 & 46 \\
\hline Guayacan scrub & Moderate & Low & Maverick clay & Rolling hardland & 36 & $20 *$ \\
\hline Creosotebush & Moderate & Low & Hidalgo-like clay loam & Shallow & 22 & $15^{*}$ \\
\hline Mesquite savannah & Thin & High & Nueces fine sand & Deep sand & 156 & 40 \\
\hline Rootplowed & Thin & Low & Zapata gravelly loam & Shallow ridge & 205 & 50 \\
\hline Granjeno drainage & Moderate & High & Miguel fine sandy loam & Tight sandy loam & 15 & $16^{*}$ \\
\hline Vegetation units between blackbrush & - & - & Mixed & - & 106 & 27 \\
\hline \multirow[t]{2}{*}{ Mesquite savannah in Colubrina scrub } & Thin & High & Nueces fine sand & Deep sand & 18 & 6 \\
\hline & & & & & 1,285 & 375 \\
\hline
\end{tabular}

\footnotetext{
${ }^{1}$ Thickness estimated by the percent visibility in types: Thicket-0 to 10 ; Thick-11 to 25 ; Moderate -26 to 50 ; Thin -51 to 75 .

${ }^{2}$ Low -2 to 4 feet; High -4 to 10 feet.

*Types oversampled due to late changes in the vegetation map.
}

\section{Study Area}

The study was conducted on the San Pedro Ranch in southwestern Dimmit County, Tex. (Fig. 1). The elevation is about $800 \mathrm{ft}$. Topography is level to rolling, and the land is dissected by intermittent streams. Average annual rainfall is 20 inches.

The 3,640-acre South Mott pasture, which made up most of the study area, was typical of brushland in South Texas. Overstory plants consisted mainly of blackbrush (Acacia rigidula), guajillo (Acacia berlandieri), and creosotebush (Larrea divaricata) on low ridges; netleaf hackberry (Celtis reticulata), granjeno (Celtis pallida), honey mesquite (prosopis glandulosa), and whitebrush (Aloysia gratissima) in the drainages; and mesquite guajillo, and Texas colubrina (Colubrina texensis) on upland deep soils.

A 205-acre brush-cleared area had been cleared with a rootplow, roller chopped, and seeded to a mixture of Kleberg bluestem (Bothriochloa ischaemum var. songarica), bufflegrass (Cenchrus ciliaris), and blue panicum (Panicum antidotale) in 1966.

The overall stocking rate on the ranch was 25 acres per animal unit of mixed breeds and herefords. An informal rotation grazing system was followed. The South Mott pasture was grazed by 276 yearling cattle during late winter (February), spring, summer, and fall of 1970 at the rate of 17 acres per animal unit. The range condition was termed fair by U. S. Soil Conservation Service technicians in 1970.

White-tailed deer densities in the southwestern part of Dimmit County (censused by airplane over a 16-mile transect) were estimated at 26 acres per deer in 1969 and 28 acres per deer in 1970 . This density is probably typical for the Rio Grande Plain.

\section{Methods}

The relative habitation by deer of 11 major brush types, a rootplowed area, and two other land areas juxtaposed with blackbrush scrub and colubrina scrub, respectively, was estimated by the pellet-group count technique (Bennett et al., 1940; McCain, 1948). Brush types of $200 \mathrm{ft}$ or more in diameter were distinguished by ocular estimates of species dominance, height, pattern, form, and thickness. Each type was named after its dominant brush plant (Table 1). Two of the most common brush types on the study area are shown in Figure 2.

With the exception of granjeno drainage, colubrina scrub, and guajillo scrub, the types were considered representative of
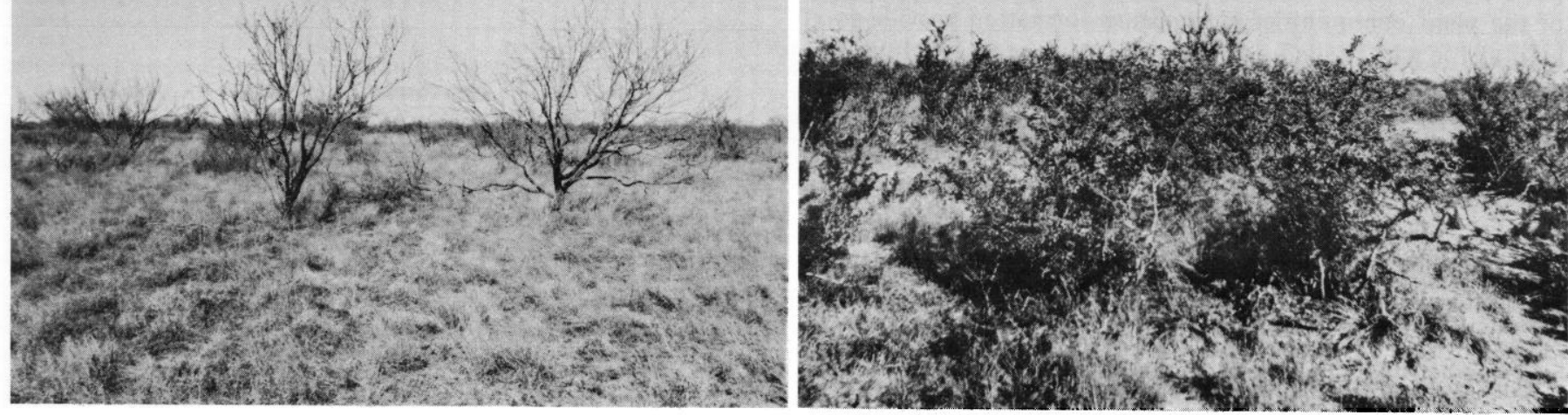

Fig. 2. The mesquite woodland on a shallow sandy loam (left) and the blackbrush scrub on a shallow ridge (right) are two contrasting types commonly found in the Rio Grande Plain. 
Table 2. Summary of analysis of variance of deer pellet-group means among brush types, within seasons.

Season and

source of variation

D. F. Mean square

Fall

Month

Brush type

Month $X$ brush type

Residual

Total

2

0.076

Month

Brush type

Month $x$ brush type

Residual

Total

13
108
1124

$0.250^{*} *$

0.028

26

0.039

0.042

124

0.060

$0.455 * *$

$0.089 * *$

0.049

0.055

Spring

Month

Brush type

0.017

Month $X$ brush type

$0.323^{* * *}$

$0.078^{* *}$

Residual

0.036

Total

0.041

Summer

$\begin{array}{lrl}\text { Month } & 2 & 0.004 \\ \text { Brush type } & 13 & 0.128^{* *} \\ \text { Month } \times \text { brush type } & 26 & 0.040^{*} \\ \text { Residual } & 1083 & 0.023 \\ \text { Total } & 1124 & 0.024\end{array}$

*Significantly different at the 0.05 level.

**Significantly different at the 0.01 level.

distinct communities occurring widely in the Rio Grande Plain. The granjeno drainage appeared as a broad xeric wash. Colubrina scrub was a secondary succession community resulting from hand clearing of brush in the 1940's. The guajillo scrub was a moderately dense stand on shallow sandy loam, atypical of the dense guajillo community that occurs on gravelly ridges in the northwestern Rio Grande Plain.

Pellet-groups were sampled on 0.01-acre circular plots placed 1 chain ( $66 \mathrm{ft}$ ) apart along randomly located transects in large, continuous examples of each major compositional brush type. Plot center markers were offset to the right of the traverse when the marker landed in impenetrable brush or cacti. Offsetting was adopted because the purpose was to determine differential use by deer on land that they could use, and not to make estimates of deer density.

Sampling intensity was 25 pellet-group plots per 100 acres of brush type sampled, so sampled brush types contained varying numbers of plots, arranged as closely as possible into 10-plot transects. All plots were swept clean in October, 1969. Pellet-groups were then counted and cleared every 30 days over a 12-month period.

The negative binomial distribution was selected to transform the original data into a normal distribution, utilizing a program devised by Gates and Ethridge (1972). The inverse hyperbolic sine, $\sinh ^{-1} y$ (Anscombe, 1948) was used to transform raw pellet-group data for analysis of variance.

The means of deer pellet-groups per plot were tested for significance among brush types within seasons. Seasons were fall (September, October, November); winter (December, January, February); spring (March, April, May); and summer (Junc, July, August). Fall season sampling was not consecutive since data from November, 1969, were grouped with those from September and October, 1970. This grouping was done because weather and vegetation conditions to mid-November of both years were generally the same and the statistical analysis of pellet-group means among brush types revealed that month was not a significant variable in the arbitrary grouping.
Duncan multiple range tests provided the basis for deer habitat rankings. Ranking indices for a type were determined by algebraically summing the number of types with significantly smaller numbers of pellet-groups $(+)$ with the number of types with significantly greater numbers $(-)$.

Abundance of plant species was estimated every second week. At the same time the phenological status of each species was characterized and assessed as to availability and use by deer.

The abundance of each plant species was coded: $1=$ very rare; $2=$ rare; $3=$ infrequent; $4=$ abundant; and $5=$ very abundant. The abundance figures were used to evaluate the similarity of brush types by means of a similarity coefficient. This was calculated by the formula $\mathrm{C}=\frac{2 \mathrm{w}}{\mathrm{a}+\mathrm{b}}$ (Bray and Curtis, 1957), where a and $\mathbf{b}$ equal the sum of the species abundance codes for the two types compared respectively, and $w$ cquals the sum of the smaller of the two abundance codes of all species shared by both types. Values range from zero, where no species are shared by the two types, compared to 1 , where all species are shared and all have equivalent abundance in both types. Separate similarity coefficients were worked out for woody plants and forbs for each pair of types.

A narrative summary of the phenology of plants was made monthly. Meteorological data were obtained from a weather station in South Mott pasture and from the Texas Agricultural Experiment Station in Crystal City (40 miles NE).

Each plant species was coded according to its availability and degree of use by deer (Dasmann, 1951). The categories were: 1 = all available, light use; 2 = all available, moderate use; 3 = all available, heavy use ; $4=$ largely available, light use; $5=$ largely available, moderate use; $6=$ largely available, heavy use; $7=$ largely unavailable; $8=$ unavailable.

Nine attributes of 0.01 -acre plots were related to variation in pellet-group densities. These were (1) brush pattern; (2) brush density; (3) brush height; (4) lower canopy height of brush; (5) plant dominance; (6) forb density; (7) grass density; (8) soil type; and (9) slope over $15^{\circ}$. During each monthly reading of the pellet-group plots, a coded appraisal was made of each parameter. A least squares analysis using the General Linear Hypothesis Program (GLYHY) (Gates, 1969) was used to analyze these data.

\section{Results}

\section{Relative Use of Brush Types}

The distribution of pellet-groups indicated that deer were selective in their use of brush types during all seasons (Table

Table 3. Annual ranking of major brush types as deer habitat based on seasonal ranking indices ${ }^{1}$ derived from Duncan multiple range tests.

\begin{tabular}{lccccc}
\hline \hline & \multicolumn{4}{c}{ Season } & Annual \\
\cline { 2 - 5 } Brush type & Fall & Winter & Spring & Summer & sum \\
\hline Mesquite drainage & +9 & +4 & +9 & +2 & +24 \\
Guajillo scrub & +7 & +4 & +9 & 0 & +20 \\
Hackberry drainage & +4 & +11 & +6 & -1 & +20 \\
Mesquite woodland & -1 & +4 & -3 & 0 & 0 \\
Mixed scrub & -2 & +1 & +1 & 0 & 0 \\
Colubrina scrub & 0 & 0 & -1 & 0 & -1 \\
Blackbrush scrub & +3 & -4 & -3 & 0 & -4 \\
Guayacan scrub & -4 & 0 & 0 & 0 & -4 \\
Creosotebush & -2 & -4 & -3 & 0 & -9 \\
Mesquite savannah & -4 & -4 & -4 & -1 & -13 \\
Rootplowed & -4 & -5 & -5 & 0 & -14 \\
Granjeno drainage & -6 & -7 & -6 & 0 & -19 \\
\hline
\end{tabular}

${ }^{1}$ Ranking indices were determined by algebraically summing the number of types with significantly smaller numbers of pellet-groups $(+)$ with the number of types with significantly greater numbers $(-)$. 


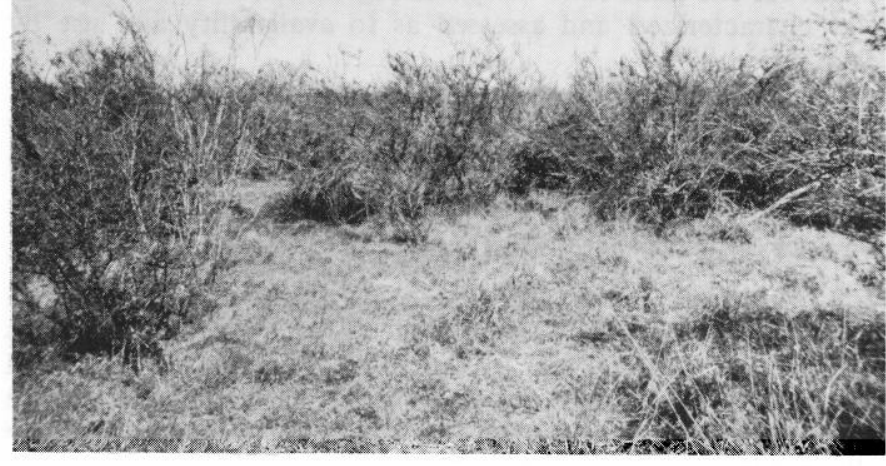

Fig. 3. Herbaceous vegetation was abundant on the mesquite drainage.

2). As shown by the significant month $X$ brush type interaction the same brush types did not attract the most deer use from month to month. However, inspection showed that this was the result of minor shifts in order of preference similar to those between seasons, discussed below.

There was a gradient in the intensity of use of brush types by deer in all seasons except summer. The mesquite drainage, guajillo scrub, and hackberry drainage were at the top of these gradients in fall, winter, and spring; granjeno drainage, rootplowed, and mesquite savannah fell at the bottom of the seasonal gradients. In summer the mesquite drainage was preferred and all other types were used about equally.

Ranking indices for each brush type (Table 3) as derived from multiple range tests showed that the mesquite drainage (Fig. 3) was the type most used by the deer herd. Guajillo scrub and hackberry drainage were the next highest ranked types with equivalent annual sums. The remainder of the brush types ranked poorly by comparison. By selecting these types and the mesquite woodland in winter, deer showed a tendency to inhabit areas of sandy loam in fall, winter, and spring.

\section{Evaluation of the Causes of Selection}

Due to an obvious difference in deer defecation rates among seasons, seasonal shifts in relative use of brush types could not be evaluated. Pellet-groups were generally greatest in winter and sequentially less in spring, fall, and summer. However, when abortive statistical tests were run, it was noted that means of pellet-groups between transects and between plots within transects were highly significant in eight of the brush types. Since the shrubs made up a fairly uniform stratum and ground cover was heterogeneous, this suggested that brush was not the primary factor governing the distribution of deer within a type.

Coefficients of similarity between pairs of brush types showed that compositional similarity to a much-used brush type did not assure that another type would be favored. In Table 4 (woody plants), each of the three types ranked highest in deer use showed as many or more species of shrubs with one of the three types ranked lowest as they did among themselves. The same was true with "similarity" of forb composition. Winter data are similar in pattern to those of other seasons. The three lowest ranked types had least similarity among themselves. Grass composition was not analyzed by similarity coefficients, but it was essentially the same in the brush types on the deep sand, loamy sand, and shallow sandy loam range sites. The brush types on the shallow and shallow ridge range sites shared a common grass cover but guayacan scrub on rolling hardland was almost entirely curly mesquite (Hilaria belangeri). Bufflegrass and blue panicum were dominants in the rootplowed type. As expected, similarity of the vegetation was greatest between types that fell on similar range sites. Generally, the vegetation of types occurring on sands or sandy loams showed least similarity to types on finer-textured soils.

Phenology of the vegetation did not appear to be a factor in deer selection of types since plants had about the same seasonal development across all types.

Neither did deer select types because of the abundance of particular plants relished as food. Joint-fir (Ephedra

Table 4. Percent similarity ${ }^{1}$ of brush and forb composition among brush types receiving most and least use by deer.

\begin{tabular}{|c|c|c|c|c|c|c|c|}
\hline & Ranking & $\begin{array}{c}\text { Mesquite } \\
\text { drain }\end{array}$ & $\begin{array}{c}\text { Guajillo } \\
\text { scrub }\end{array}$ & $\begin{array}{c}\text { Hackberry } \\
\text { drain }\end{array}$ & $\begin{array}{l}\text { Mesquite } \\
\text { savannah }\end{array}$ & $\begin{array}{l}\text { Root- } \\
\text { plowed }\end{array}$ & $\begin{array}{c}\text { Granjeno } \\
\text { drain }\end{array}$ \\
\hline & Woody plants & & & & & & \\
\hline \multirow{17}{*}{ - } & Most use & & & & & & \\
\hline & Mesquite drainage & - & & & & & \\
\hline & Guajillo scrub & 48 & - & & & & \\
\hline & Hackberry drainage & 46 & 27 & - & & & \\
\hline & Least use & & & & & & \\
\hline & Mesquite savannah & 45 & 34 & 37 & - & & \\
\hline & Rootplowed & 42 & 60 & 19 & 18 & - & \\
\hline & Granjeno drainage & 48 & 26 & 62 & 38 & 19 & - \\
\hline & Forbs (winter) & & & & & & \\
\hline & Most use & & & & & & \\
\hline & Mesquite drainage & - & & & & & \\
\hline & Guajillo scrub & 56 & - & & & & \\
\hline & Hackberry drainage & 47 & 21 & - & & & \\
\hline & Least use & & & & & & \\
\hline & Mesquite savannah & 34 & 45 & 18 & - & & \\
\hline & Rootplowed & 47 & 44 & 23 & 26 & - & \\
\hline & Granjeno drainage & 40 & 34 & 52 & 22 & 32 & - \\
\hline
\end{tabular}

\footnotetext{
${ }^{1}$ Similarity coefficient $=\frac{2 w}{a+b}$, where $a$ and $b$ equal the sum of the species abundance codes for the 2 types compared, and $w$ equals the sum of the smaller of the 2 abundance codes of all species shared by both types.
} 


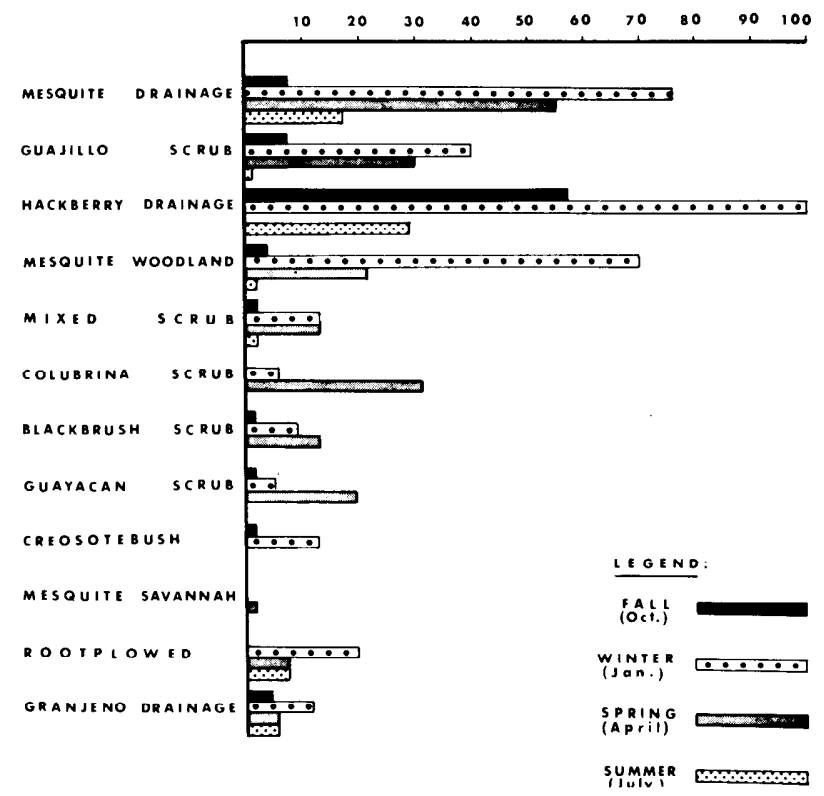

Fig. 4. Percentage of 0.01 -acre pellet-group plots within each major brush type (ranked in decreasing order of deer preference) where forbs were classed as dense.

antisyphlitica), palo verde (Cercidium texanum), and kidneywood (Eysenhardtia texana) were the shrubs receiving heavy use by deer where found, but they were not associated with any particular brush type. Of the forbs, only alkali sida (Sida hederacea), sensitivebriar (Schrankia sp.), bloodberry rougeplant (Rivina humilis), and knotweed leafflower (Phyllanthus polygonoides) received heavy grazing by deer. But these forbs were generally classed as rare or infrequent in the preferred brush types.

Use of grasses by deer was impossible to determine since cattle grazed the South Mott pasture, but this class of forage is generally considered important to deer as food only in spring when annuals are in evidence on almost all range sites.

\section{Least Squares Analysis of Pellet-group Densities and Param- eters of Site}

Selection of sites appeared to be significantly related to (1) dominance by leatherstem (Jatropha dioica) $(P<0.01)$ or guajillo $(P<0.01)$; (2) forb density $(P<0.01)$; (3) grass density $(P<0.01)$; and $(4)$ soil type $(P<0.01)$. Plots with stands of leatherstem and guajillo had the highest mean number of pellet-groups. Leatherstem is not browsed by deer; however, the plant has a high fidelity to the guajillo scrub type on shallow sandy loam range sites. The dense classes of forbs and grasses were associated with the highest pellet-group means, as were the sandy loams among soil types. Of the ecological parameters associated with the sample plots, only these four had an orderly relationship to the abundance of pellet-groups. None of the structural attributes of brush (composition, pattern, form, or density) had such a relationship.

Because many possible combinations of conditions did not occur, only two interactions could be tested; forb density $X$ grass density, and forb density $X$ soil type. The former interaction was significant $(P<0.01)$, while the latter was not. Pellet-group means associated with the interaction of forb and grass densities showed that dense stands of forbs and grass were about equally attractive. The highest mean was associated

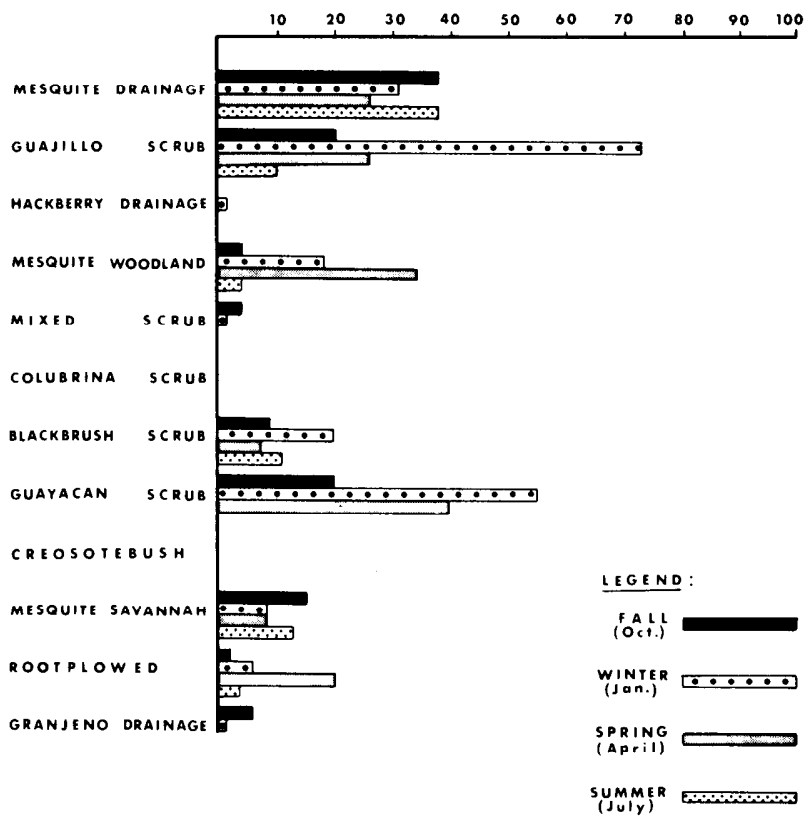

Fig. 5. Percentage of 0.01 -acre pellet-group plots within each major brush type (ranked in decreasing order of deer preference) where grasses were classed as dense.

with dense forbs and moderately dense grass $(\bar{x}=0.852)$, followed by the mean for sparse forbs and dense grass $(\overline{\mathrm{x}}=$ $0.848)$. The least attractive situation was that in which forbs were moderately dense and grass was sparse $(\bar{x}=0.683)$. Intermediate means of pellet-groups were greater as the combined density of forbs and grasses increased.

The highest percentage of plots with dense herbaceous plants occurred in the preferred types (Fig. 4,5). The relative paucity of grass in hackberry drainage was apparently compensated for by dense forbs. The density of herbs, the sandy loam soils, and the occurrence of guajillo were factors most important in the selection of both site and type of brush.

\section{Discussion}

Except for guajillo, the characteristics of the woody overstory do not appear to be important criteria for deer selection of type within the range of compositional types, stature, and density of San Pedro Ranch brush.

The reason brush species do not elicit any more response among deer is probably because so many species of similar growth form provide adequate food, cover, and shelter. Only a few brush species are especially relished by deer as food, so almost any plant will be browsed; and since browse is less palatable than herbs (Drawe and Box, 1968), a moderately dense stand of almost any brush species would serve as food. The apparent affinity of deer for guajillo shrubs is puzzling since the plant was only lightly browsed during our study; however, the attraction may lie in the high quality of its leaves as food.

The minimum density of brush that makes land habitable for deer remains an unanswered question, but the rootplowed land clearly was below this threshold. Mesquite savannah (Fig. 6) was probably near the limit. The absence of brush for screening cover is likely the reason for the very limited use of open land by deer.

It is clear that deer tolerate a wide range of brush attributes, given a basic cover screen, and within this range 


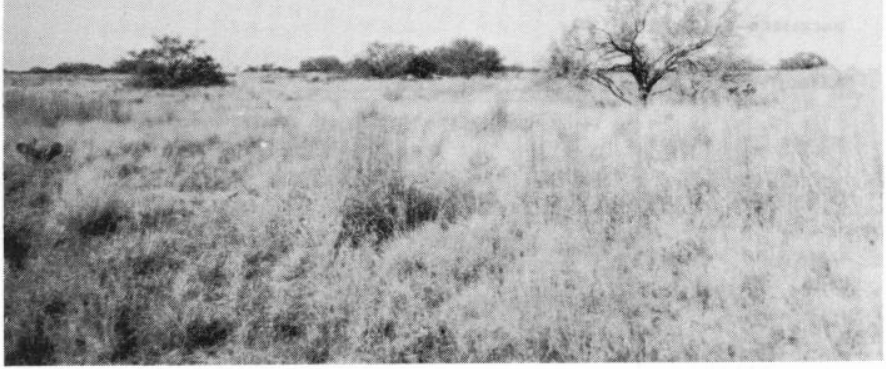

Fig. 6. The mesquite savannah. Note abundance of herbaceous vegetation, and near absence of brush as screening cover for deer.

they respond more to herbaceous vegetation than to any of the other environmental factors considered. Avoidance of the granjeno drainage by deer gave further evidence that herbaceous plants are paramount in deer selection of habitat. Brush was abundant and varied in the granjeno drainage, as it was in the mesquite and hackberry drainages, but the relief of the granjeno drainage was not so pronounced. Consequently, effective water for plant growth appeared to be less than that available to the hackberry and mesquite drainages located in deeper valleys. This condition probably accounted for the paucity of herbaceous vegetation as compared to the other drainage types despite the common soil type. If herbaceous plants had little to do with the selection of habitat, the expectation would be that granjeno drainage would be utilized to the same extent as the mesquite or hackberry drainages. But granjeno drainage was clearly selected against.

The indicated attraction that deer show for the brush types types on sandy loam range sites is probably associated with improved moisture conditions for herbaceous plant growth. Sandy loams tend to have more moisture for effective plant growth after rain showers than clays or clay loams. The prevalance of improved moisture conditions for plant growth on sandy loams would seem to explain the preference by deer for the mesquite and hackberry drainages, guajillo scrub, and mesquite woodland during the wet winter season. With the advent of the dry season these improved conditions may become less apparent, except in the more shady drainages, and this could account for the selection of the mesquite drainage in summer. The negative response by deer to hackberry drainage in summer probably resulted from rank growth of field ragweed (Ambrosia confertiflora), and Mexican sagewort (Artemisia ludoviciana) to the exclusion of more succulent forbs and grasses.

White-tailed deer use of San Pedro brushland may be summarized as follows: Brush to deer is simply brush; the animals do not distinguish between compositional types of brush, or between any of the structural attributes of brush, such as height, pattern, or density. But lack of brush over extensive areas causes much reduced use by deer. Deer are attracted to dense herbaceous vegetation; thus, the quality of typical brushlands as deer habitat is largely a function of the range site. Deer make use of all the major range sites and most lesser ones, provided the brush is not impenetrable or very sparse. When the deer population has a good interspersion and choice among range sites, the sandy loams having more dense herbaceous vegetation are favored in fall, winter, and spring.

\section{Management Implications}

The ranch manager who is concerned with deer habitat should pay particular attention to drainages and uplands with sandy loam soils in formulating a brush clearing plan. Considering the relatively small acreages of drainages, their productivity, and high degree of use by deer, it would seem wise to leave them intact for deer habitat. Upland sandy loam range sites could be treated in a variety of ways to provide for deer. Moderate to low density brush could be left untreated. Treatment of dense brush on extensive acreages of shallow sandy loam or of any range site highly productive of native herbs should include leaving some pattern of brush within the clearings as cover. In this way the herbaceous plants shown to be so attractive for deer could be better utilized by the herd.

\section{Literature Cited}

Anscombe, F. J. 1948. The transformation of Poisson, binomial, and negative binomial data. Biometrika 3:246-254.

Bennett, L. J., P. F. English, and R. McCain. 1940. A study of deer populations by use of pellet-groups. J. Wildl. Manage. 4:398-403.

Bray, J. R., and J. T. Curtis. 1957. An ordination of the upland forest communities of southern Wisconsin. Ecol. Mongr. 27:325-349.

Dasmann, W. P. 1951. Some deer range survey methods. California Fish and Game 37:43-52.

Davis, R. B., and R. L. Spicer. 1965. Status of the practice of brush control in the Rio Grande Plain. Texas Parks and Wildlife Bull. 46. $40 \mathrm{p}$.

Davis, R. B., and C. K. Winkler. 1968. Brush vs. cleared range as deer habitat in southern Texas. J. Wildl. Manage. 32:321-329.

Drawe, D. L., and T. W. Box. 1968. Forage ratings for deer and cattle on the Welder Wildlife Refuge. J. Range Manage. 21:225-235.

Gates, C. E. 1969. GLHYP documentation (General Linear Hypothesis). Unpubl. mimeo. paper, Inst. Stat., Texas A \& M Univ., College Station. 30 p.

Gates C. E., and F. G. Ethridge. 1972. A generalized set of discrete frequency distributions with FORTRAN program. Mathematical Geology 4:1-24.

Inglis, J. M. 1964. A history of vegetation on the Rio Grande Plain. Texas Parks and Wildlife Bulletin. 45. 122 p.

Johnston, M. C. 1963. Past and present grasslands of southern Texas and northeastern Mexico. Ecology 44:456-466.

McCain, R. 1948. A method for measuring deer range use. Trans. North America Wildlife. Natural Resources Conference. 13:431-440.

Muller, C. H. 1947. Vegetation and climate of Coahuila, Mexico. Madrono 9:33-57. 